\title{
Therapeutic Potentials of Shirisha (Albizia lebbeck Benth) - A Review
}

\author{
Review article
}

\begin{tabular}{|c|}
\hline Shyamlal Singh Yadav $^{1}$, M. Jaiswal ${ }^{2}$, Galib $^{3}$, P. K. Prajapati ${ }^{4}$ \\
\hline $\begin{array}{l}\text { 1. Ph.D } 1^{\text {st }} \text { Year Scholar. Department of Rasashastra and Bhaishajya Kalpana including Drug Research } \\
\text { 2. Lecturer, Department of Rasashastra and Bhaishajya Kalpana, State Ayurvedic College, Lucknow. } \\
\text { 3. Asst. Professor, Department of Rasashastra and Bhaishajya Kalpana including Drug Research. } \\
\text { 4. Prof. \& Head, Department of Rasashastra and Bhaishajya Kalpana including Drug Research. }\end{array}$ \\
\hline
\end{tabular}

\begin{abstract}
$\underline{\text { Abstract }}$
Albizia lebbeck Benth. is a large, erect, unarmed, deciduous, spreading tree belonging to the family Fabaceae (Formerly Leguminosae), member of the subfamily Mimosaceae. It is found throughout India, ascending to $900 \mathrm{~m}$ in the Himalayas and also in the islands of Andaman. It contains saponins, macrocyclic alkaloids, phenolic glycosides and flavonoids. In Ayurveda, Albizia lebbeck Benth. is familiar as Shirisha and it has been attributed with properties like Vishaghna (anti-poisonous) and emphasized its efficacy in Visarpa (Erysipelas), Hicca (Hiccup), Shwasa (Breathlessness), Kasa (Cough) etc. Researches of recent past have also reported anti-inflammatory, anti-histaminic, anti-anaphylactic, anti-asthmatic, anti-microbial properties of the plant. Saponins isolated from the methanolic extract of bark and pod of Albizia lebbeck Benth. have found to possess anti-spermatogenic effect. The current review revealed that, the plant Shirisha has a number of potentials in therapeutic field.
\end{abstract}

Keywords: Albizia lebbeck, Shirisha, Vishaghna, Shwasa, Ayurveda.

\section{Introduction}

Albizia lebbeck Benth.(Figure1:a)

is a large, erect, unarmed, deciduous, spreading tree belonging to the family Fabaceae (Formerly Leguminosae), member of the subfamily Mimosaceae.(1) It is found throughout India, ascending to $900 \mathrm{~m}$ in the Himalayas and also in the Andmans.(2) In Hindi, the plant is commonly known as Shirisha. Other Vernacular names are

\footnotetext{
*Corresponding author:

Dr. Shyamlal Singh Yadav

Ph.D Scholar,

Dept. of Rasashastra and Bhaishajya

Kalpana Including Drug Research

IPGT\&RA,

Gujarat Ayurved University, Jamnagar.

E-mail: drshyamlal80@gmail.com

Mob: 09913376548
}

\author{
Sanskrit: Barhapuspha, Bhandi, \\ Kalinga, \\ English: Parrot tree, East Indian \\ walnut, Fry wood, \\ Urdu: Darash, \\ Gujrati: Pilo sarashio, \\ Telugu: Dirisena, \\ Kannada: Bage mara, \\ Tamil: Vagie, \\ Punjabi: Sareehn, \\ Marathi: Chichola, Kala shiras.
}

The word Albizzia has came from Albizia an Italian naturalist of the eighteenth century.(3) Bark (figure-1d) is dark brown to greenish black, rough, with longitudinal and transverse fissures on outer surface; inner surface whitish with fine longitudinal stations. The sapwood (figure-1b) is white or yellowish white and the heartwood (figure-1b) is dark brown, streaked with dark and white shades. 
Leaves bipinnate with 8-18 leaflets. Flowers (figure-1c) are stalked, greenish yellow. Flowering and fruiting season starts from April to June. Pods (figure-1e) yellowish brown with 6-10 seeds. Mature pods remain on the tree for long period and are available till May-July. The tree is a good substitute for Teak (Tectona grandis Linn) and Sala (Shorea robusta Gaertn.), The tree is very good nitrogen fixing plant. (4)

Figure 1

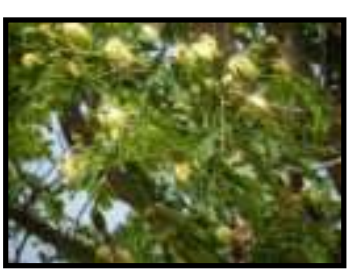

a: Whole plant

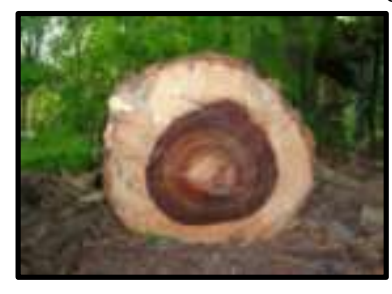

b: A- Bark, B-Sapwood, C-Heartwood

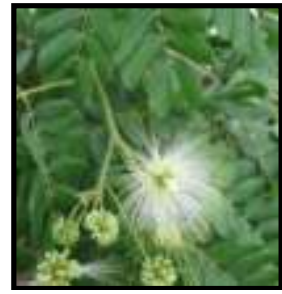

c: Compound leaf with inflorescence

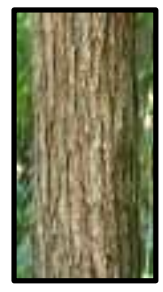

d: Stembark;

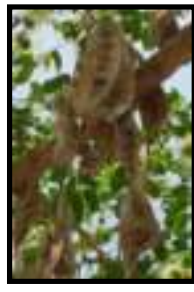

e: Pod

mechanisms of action or attributes of a substance viz. Rasa (taste), Guna (property), Vipaka (metabolites), Virya (potency) and Prabhava (specific action); which have been depicted at Table-1. on biophysical, experiential, inferential and intuitional mechanism. The action of Dravya (substance) is based on five

Table 1: Ayurvedic Properties of Albizia lebbeck Benth. (5-6)

\begin{tabular}{|c|c|c|c|c|}
\hline Rasa & Guna & Virya & Vipaka & Prabhava \\
\hline Tikta, Kasaya, & Laghu, Tikshna, & Anushna & Katu & $\begin{array}{c}\text { Tridosha shamaka, } \\
\text { Mishaghna }\end{array}$ \\
\hline
\end{tabular}

Table 2: Karma (Pharmacodynamics) and Prayoga (uses) of Shirisha.

\begin{tabular}{|l|l|l|}
\hline \multicolumn{1}{|c|}{ Karma } & \multicolumn{1}{|c|}{ Prayogas } & \multicolumn{1}{c|}{ Reference } \\
\hline Visarpaghna (Anti-Erysipelas) & Shosha, Kasa, Vrana, Visha & $\begin{array}{l}\text { Bhavaprakash } \\
\text { Nighantu (7) }\end{array}$ \\
\hline Vishahara (Anti-Poisonous) & $\begin{array}{l}\text { Pama, Kushtha, Kandu, } \\
\text { Twakdosh }\end{array}$ & Raja Nighantu (8) \\
\hline $\begin{array}{l}\text { Raktastambhana (styptic), Balya } \\
\text { (tonic) }\end{array}$ & $\begin{array}{l}\text { Arsha, Shopha, visarpa, } \\
\text { bhagna }\end{array}$ & $\begin{array}{l}\text { Shodhala Nighantu } \\
\text { (9) }\end{array}$ \\
\hline Tridosha shamana, Varnya & $\begin{array}{l}\text { Kustha, Kandu, Shwasa, } \\
\text { Kasa, Vrana. }\end{array}$ & $\begin{array}{l}\text { Kayaideva } \\
\text { Nighantu(10) }\end{array}$ \\
\hline Tridosha shamana, Varnya & $\begin{array}{l}\text { Kustha, kandu, Shwasha, } \\
\text { Kasa, Twaka dosha. }\end{array}$ & $\begin{array}{l}\text { Dhanvantari } \\
\text { Nighantu (11) }\end{array}$ \\
\hline $\begin{array}{l}\text { Vishaghna,(anti-poisonous), Vedana } \\
\text { sthapana (analgesic) }\end{array}$ & $\begin{array}{l}\text { Hicca, Shwasa, Visarpa, } \\
\text { Sarpa Visha }\end{array}$ & $\begin{array}{l}\text { Charaka Samhita } \\
(12)\end{array}$ \\
\hline $\begin{array}{l}\text { Shiro virechana, Vishahara, Pitta } \\
\text { nashana }\end{array}$ & $\begin{array}{l}\text { Kustha, Arsha, Ashmari, } \\
\text { Visha }\end{array}$ & Susruta Samhita (13) \\
\hline
\end{tabular}

Therapeutic attributes of Shirisha in classics

Albizia lebbeck Benth has been attributed as par-excellence drug in cases of Visha(12). Its bark is used as Lepa (external medicament) in erysipelas.(14) Albizia lebbeck Benth. Seed is used in Ardhavabhedaka and Unmada in the form 
of Nasya.(15) Swarasa of Shirisha Pushpa is indicated in Sarpa visha (snake bite) with Sobhanjana (Moringa olifera)(16) and useful in Hicca, Shwasa along with Pippli (Piper longum) and Maddhu(17). Panchshirisha Agada, a preparation of 5 parts of Albizia lebbeck Benth. is recommended in the treatment of all types of poisonings.(18) Amrita Ghrita(19), Gandhahasti Agada(20), Maha Gandhahasti Agada(21) and Shirisharishta(22) are few compound formulations with Shirisha as a component, which have been indicated in cases of Visha.

Pharmacological properties of various parts of Shirisha in different dosage forms in Brihatrayi:

1. Charaka Samhita

\begin{tabular}{|c|c|c|c|c|}
\hline & Part used & Dosage form & Disease & Reference \\
\hline \multirow[t]{5}{*}{1.} & \multirow[t]{5}{*}{ Beeja $($ Seed $)$} & $\begin{array}{l}\text { Shiro virechana } \\
(\text { Nasya })\end{array}$ & $\begin{array}{l}\text { Shiraha shoola, } \\
\text { Ardhavabhedaka, } \\
\text { Kushtha }\end{array}$ & Ch. Su. 2/5 \\
\hline & & Nasya /Anjana & Unmada & Ch. Chi. 9/64-65 \\
\hline & & Pralepa & Arsha & Ch. Chi. 14/53 \\
\hline & & Nasya & Shiro roga & Ch. Chi. 26/184 \\
\hline & & Nasya / Pana / Anjana & Luta Visha & Ch. Chi. 23/200 \\
\hline \multirow[t]{6}{*}{2.} & \multirow[t]{6}{*}{ Twak (Bark) } & Lepa & Visha & Ch. Su. $3 / 28$ \\
\hline & & Lepa & Kushtha & Ch. Chi. 7/96 \\
\hline & & $\begin{array}{l}\text { Siddharthakadi yoga } \\
\text { (lepa) }\end{array}$ & Unmada & Ch. Chi. $9 / 70$ \\
\hline & & Lepa & Visarpa & Ch. Chi. 21/84 \\
\hline & & Amritghrita & Visha & Ch. Chi. 23/242 \\
\hline & & Mulaka taila & $\begin{array}{l}\text { Pleeharoga / Shwasa / } \\
\text { Kasa }\end{array}$ & Ch. Chi. 28/172 \\
\hline \multirow[t]{6}{*}{3.} & \multirow{6}{*}{$\begin{array}{l}\text { Pushpa } \\
\text { (Flower) }\end{array}$} & Swarasa & Hikka/Shwasa & Ch. Chi 17/114 \\
\hline & & Lepa & Visarpa & Ch. Chi 21/90-91 \\
\hline & & Swarasa & Visha & Ch. Chi 23/52 \\
\hline & & Mrita Sanjivani Agada & Visha & Ch. Chi. 23/54 \\
\hline & & Nasya / Pana / Anjana & Visha & Ch. Chi. 23/193 \\
\hline & & Gandhahasti Agada & Visha & Ch. Chi. 23/71 \\
\hline \multirow[t]{2}{*}{4.} & \multirow[t]{2}{*}{ Phala (Fruit) } & Lepa / Nasya / Pana & Visha & Ch. Chi. 23/53 \\
\hline & & Lepa & Medhaka Visha & Ch. Chi 23/209 \\
\hline \multirow[t]{2}{*}{5.} & \multirow{2}{*}{$\begin{array}{l}\text { Panchanga } \\
\text { (Whole Plant) }\end{array}$} & Pana /Lepa & Visha & Ch. Chi 23/218 \\
\hline & & $\begin{array}{l}\text { Maha Gadhahasti } \\
\text { Agada }\end{array}$ & Visha & Ch. Chi. $23 / 78$ \\
\hline 6. & Patra (Leaf) & Swarasa (Nasya) & Visha & Ch. Chi 23/49 \\
\hline 7. & $\begin{array}{l}\text { Sara } \\
\text { (Heart wood) }\end{array}$ & Asava & -- & Ch. Su. 25/49 \\
\hline \multirow[t]{6}{*}{8.} & \multirow[t]{6}{*}{$* * *$} & Lepa & Tvag dosha & Ch. Su. 3/29 \\
\hline & & Maha Kashaya & Vishaghna & Ch. Su. 4/16 \\
\hline & & Maha Kashaya & Vedana Sthapana & Ch. Su. 4/47 \\
\hline & & Agrya dravya & Vishaghnanam & Ch. Su. $25 / 40$ \\
\hline & & Kashaya Skanda & -- & Ch. Vi. $8 / 144$ \\
\hline & & Shiro Virechana & -- & Ch. Vi. 8/151 \\
\hline
\end{tabular}




\begin{tabular}{|l|l|l|l|}
\hline \multirow{2}{*}{} & Churna $($ Lepa $)$ & Kikkisa & Ch. Sha. 8/32 \\
\cline { 2 - 4 } & Kwatha & Pittaja Prameha & Ch. Chi. 6/31 \\
\cline { 2 - 4 } & Churna (Lepa) & Tvaga dosha, Dadru & Ch. Su. 3/4 \\
\hline
\end{tabular}
*** Part used is not mentioned in the classic.

2. Sushruta Samhita

\begin{tabular}{|c|c|c|c|c|}
\hline \multirow{2}{*}{1} & \multirow[t]{2}{*}{ Beeja $($ Seed $)$} & Pratisarana & Visha & Su. Kalp. $1 / 50$ \\
\hline & & Churna & Netra Vikara & Su. U. $12 / 28$ \\
\hline \multirow{2}{*}{2} & \multirow[t]{2}{*}{ Puspa (Flower) } & Anjana & Netra Vikara & $\begin{array}{l}\text { Su. U. 12/16, } \\
12 / 31\end{array}$ \\
\hline & & $\begin{array}{l}\text { Banshagatwadi } \\
\text { agada(lepa,nasya,) }\end{array}$ & Luta visha & Su. Kalp 5/79 \\
\hline \multirow{3}{*}{3} & \multirow[t]{3}{*}{ Phala (Fruit) } & Shiro virechana & -- & Su. Su. 39/6 \\
\hline & & Churna & Avasadana & Shu. Su. $37 / 33$ \\
\hline & & Lepa & Arsha & Su. Chi. 6/12 \\
\hline 4 & Panchanga (Whole plant) & Kwatha & Visha & Su. Kalp 5/81 \\
\hline \multirow{10}{*}{5} & \multirow[t]{7}{*}{$* * *$} & Ghrita & Pittaja Ashmari & Su. Chi. 7/11 \\
\hline & & Lepa & Dadru Nashaka & Su. Chi. 9/14 \\
\hline & & Vajrak taila & Nadi Vrana & Su. Chi. 9/54 \\
\hline & & Maha Vajrak Taila & Kushta & Su. Chi. $9 / 59$ \\
\hline & & Kwatha & Hasti meha & Su. Chi. 11/9 \\
\hline & & $\begin{array}{l}\text { Dhanwantari } \\
\text { Ghrita }\end{array}$ & Prameha Pidaka & Su. Chi. 11/5 \\
\hline & & Lepa & Shirah Shoola & Su. Kalp. 1/36 \\
\hline & & -- & Kushta & Su. Su. 38/12 \\
\hline & & Yavagu & Visha & Su. Kalp. 2/45 \\
\hline & & -- & Sarpa Visha & Su. Kalp 5/18 \\
\hline
\end{tabular}

*** Part used is not mentioned in the classic.

\section{Asthanga Hridaya}

\begin{tabular}{|c|c|c|c|c|}
\hline \multirow{2}{*}{1} & \multirow[t]{2}{*}{ Beeja (Seed) } & Mukha Lepa & Vyanga & A H Su 22/19 \\
\hline & & Lepa & Arsha & A H Chi $8 / 24$ \\
\hline \multirow{4}{*}{2} & \multirow[t]{4}{*}{ Puspa (Flower) } & Anjana & Netra Vikara & $A H U 11 / 44$ \\
\hline & & Pishanjana & Netra Vikara & $A H U 15 / 31$ \\
\hline & & Swarasa & Shwasa & A H Chi 4/32 \\
\hline & & Lepa & Visarpa & A H Chi 18/16 \\
\hline \multirow{2}{*}{3} & \multirow[t]{2}{*}{ Twak (Bark) } & Lepa & Kushta & A H Chi 19/63 \\
\hline & & Vajraka Taila & Kushta & A H Chi 19/79 \\
\hline 4 & Patra (Leaf) & Swedana & -- & A H Su 17/13 \\
\hline \multirow{2}{*}{5} & \multirow[t]{2}{*}{$* * *$} & Swarasa & Shirah shula & A H Chi 20/26 \\
\hline & & Ghrita & Ashmari & A H Chi 11/23 \\
\hline
\end{tabular}

*** Part used is not mentioned in the classic. 
Ethanobotanical, folk and tribal uses of Albizia lebbeck Benth:

Albizia lebbeck Benth. has a long history of use in Indian traditional medicine, particularly for the treatment of Asthma and allergic disorders. Seeds are astringent and have values in piles and diarrhea.

Bark has been used in Ayurveda for the treatment of bronchial asthma, leprosy, eczema, pruritus, paralysis, gum inflammation, anti-inflammatory agent and worm infestation.(23-27) Though, all the parts of the plant are prescribed in the treatment venomous bites; no part of the plant has antidotal value against either snake or scorpion.(28)

\section{Phytochemical Study:}

Leaf contains saponins, tanins and Two new tri- $O$-glycoside flavonols: kaempferol and quercetin3- $O-\alpha-$ rhamnopyranosyl (1'6)- $\alpha$-glucopyranosyl (1'6)- $\alpha$-galacto pyranosides.(29-30) Pods contains 3',5 dihydroxy4',7 dimethoxy flavone and N-benzoyl L Phenyl alaninol(30). The beans of the plants contain albiginc acid- a new triterpenoid sapogenin(31). Plant bark contain two saponin known as libbekenin A \& B, Three Saponin albiziasaponins A, B and C.(32-34) Condensed tannins (7-11\%) \& d- catechin, libbecacidin, isomers of leucocyanidin, friedellin-3-one, acacic acid, Echinocystic acid and $\beta$ - sitosterol. A saponin - lebbekenin $\mathrm{C}$, on acid hydrolysis yielded echinocystic acid, glucose and rhamnose.(35-37) The heartwood contains Melanoxetin, d-pinitol, okanin \& leucopelangonidin, a stereoisomer (-) melacacidin $\left(7,8,3^{\prime}, 4^{\prime}\right.$ - tetrahedroxyflavan3,4-diol), lebbecacidin, two new compounds 2,3-cis-3,4-cis-3, $\Omega$-methylmelacacidin and 3'-O-methylmelonoxetinisolated from heartwood(38). Root Saponin characterized as echynocystic acid-3-0-L-rhamnopyranosyl $(1 \rightarrow 5)$ - $\beta$ - Dxylofuranolsyl $\quad(1 \rightarrow 4)-\quad \beta$-Dglucopyranoside.(39-40) Flower contains
Triterpene, saponin, lebbekanin, saponin glycosides, and crocetin lebbekanin$\mathrm{D}, \mathrm{F}, \mathrm{G} \& \mathrm{H}$, the flower on steam distillation gave $4.3 \%$ colorless sweet smelling oil and the residue gave lupiol.(41)

\section{Analysis of seed (42):}

Seeds are rich in proteins and can be included in animal diets.

$\begin{array}{ll}\text { Crude fibers } & -4.2 \% \\ \text { Nitrogen free extract } & -45.3 \% \\ \text { Crude protein } & -39.5 \% \\ \text { Ether extract } & -6.8 \% \\ \text { Total ash } & -4.2 \% \\ \text { Moisture } & -8.2 \% \\ \text { Pentose } & -16.9 \% \\ \text { Water soluble gum } & -2.3 \% \\ \text { Oil } & -5.3 \%\end{array}$

Analysis of heartwood (43):

$\begin{array}{ll}\text { Ether extract } & -0.96 \% \\ \text { Hot water extract } & -14.4 \% \\ \text { Lignin } & -22.0 \% \\ \text { Holocellulose } & -76.9 \% \\ \alpha \text {-cellulose } & -45.60 \%\end{array}$

Analysis of leaves (44-45): Leaves are palatable, nutritious and can be used as fodder.

$\begin{array}{ll}\text { Dry matter } & -36.8 \text { to } 44.2 \% \\ \text { Crude protein } & -20.1 \text { to } 21.1 \% \\ \text { Ether extract } & -8.5 \text { to } 16.0 \% \\ \text { Crude fibers } & -16.7 \text { to } 19.0 \% \\ \text { Total ash } & -10.1 \text { to } 10.4 \% \\ \text { Total carbohydrate } & -52.5 \text { to } 61.3 \% \\ \text { Calcium } & -3.6 \text { to } 4.3 \% \\ \text { Phosphorus } & -0.03 \text { to } 0.04 \%\end{array}$

\section{Pharmacological contrive:}

1. Anti-asthmatic activity: Clinical studies of stem bark decoction reported significant decrease in WBC, eosinophilic count, ESR, and 56\% marked improvement (46). Shrisharista was given in 48 cases of bronchial asthma at a dose $40 \mathrm{ml}$ per day for one month. The result indicated 
that $36.59 \%$ patients got mild improvement, $43.90 \%$ patients got moderate improvement and $7.32 \%$ patients got marked improvement.(47) Shireeshadi Ghana Vati in a dose of 1 gm QID with water provided $40 \%$ showed marked improvement and 20\% mild improvement in cases of Bronchial Asthma. No adverse reactions were reported.(48) Decoction of the flower in the dose of $50 \mathrm{mg} / \mathrm{kg}$ body weight has significant action against histamine induced bronchospasm. The activity could be due to smooth muscle relaxation.(49)

2. Effect on anaphylactic shock: The decoction of the bark had a significant cromoglycate like action on the mast cells of albino rats. Studies indicate the anti-anaphylactic activity is due to inhibition of the synthesis antibodies and suppression of T-lymphocytes activity.(50) The crude extract of the seeds and a pure saponin fraction at a dose of $0.5 \mathrm{mg} / \mathrm{ml}$ had exhibited stabilizing effect on the mast cells in the mesentery and peritoneal fluid of rats subjected to anaphylaxis.(51)

3. Pulmonary eosinophilia: Preliminary screening in 35 cases of tropical pulmonary eosinophilia treated with extracts of Shirisha pushpa in a dose of $200 \mathrm{mg}$ twice a day with water indicated $82 \%$ marked response, $12 \%$ good response and $6 \%$ poor response. No Adverse Effects were reported in the study.(52)

4. Anti-tussive activity: Shirishavaleha exhibited anti-tussive activity on sulphur dioxide induced cough in experimental animals. Result indicated significantly decreased cough episodes in comparison to control group.(53)

5. Allergic conjunctivitis: In a comparative clinical study, Ghana satva of Shirisha bark and Shirisha Churna capsules showed encouraging results in all kinds of allergic conjunctivitis.(54)
6. Anti-fertility activity: Methanolic extract of pod of Shirisha shown antisprematogenic activity by reduction in spermatocyte \& spermatogonia count, reduction in sperm density \& sperm motility and decreased size of testes, epididymis, and seminal vesicle and prostrate in male rats.(55) Oral administration of isolated saponin from bark of Shirisha in the dose of 50mg / $\mathrm{kg}$ body weight in male rats resulted in a significant decrease in weight of testes, epididymis, seminal vesicle \& ventral prostate. No significant changes could be observed in hematological and biochemical parameters as well.(56) Saponins obtained from seeds at dose of 200 $\mathrm{mg} / \mathrm{kg}$ inhibited copper-induced ovulation in $60 \%$ of rabbits and caused marked reduction in average number of bleeding points in the ovaries.(57) The ethanolic extract of pods and root at a concentration of $2 \%$ as well as the saponins, lebbekanin-E exhibited spermicidal activity in rats and human semen.(58-60)

7. Anti-diarrheal activity: Aqueous and methanolic extracts of Shirisha exhibited activity against E. coli \& Salmonella species. While Petroleum ether \& hexane extracts did not exhibit any activity. None of the extracts showed activity against Shigella \& Candida sp.(61) It has also been shown moderate activity against $\mathrm{V}$. cholerae, A.hydrophilis and B. subutilis.(62)

8. Antimicrobial activity: The Glycosides isolated from the stem bark exhibited antimicrobial activity against staphylococcus aureus, Pseudomonas aeruginosa, Trichophyton rubrum.(63)

9. Anti-inflammatory activity: Methanol extract of bark at the dose of $400 \mathrm{mg} / \mathrm{kg}$ inhibited $36.68 \%(\mathrm{p}<0.001)$ of edema at the end of $4 \mathrm{hr}$.(64) Antiinflammatory effect of Shirishavaleha has been reported significant at the end of 6 hours $(60.14 \%, p<0.05)$ in 
comparison to control group (35.55\%).(65) Aller-7, a botanical formulation of Albizia lebbeck Benth. along with six other plants exhibited potent activity against different inflammatory responses because of mast cell stabilization, lipoxygenase inhibition, hyaluronidase inhibition in number of in vitro models tested.(66)

10. Analgesic activity: The peripheral analgesic activity of Shirisha was measured by the acetic acid induced writhing test. The bark extract at $400 \mathrm{mg} / \mathrm{kg}$ dose showed significant $(\mathrm{p}<0.001)$ reduction in the number of writhes with $52.4 \%$ of inhibition.(67) The central analgesic activity of the plant material was studied by measuring the drug induced changes in the sensitivity of the pre screened (Reaction time 2-4 sec) mice to heat stress applied to their tails by using a medicraft Analgesiometer- $\mathrm{N}$ (D'Amour and Smith 1941). The crude extract produced $61.48 \%(\mathrm{p}<0.001)$ elongation of tail flicking time $30 \mathrm{~min}$ after oral dose of $400 \mathrm{mg} / \mathrm{kg}$. The plant extract showed prolonged stress tolerance capacity in the mice, indicating the possible involvement of higher centres.(68) The bark administered in a dose of $250 \mathrm{mg} / \mathrm{kg}$ i.p. showed analgesic activity being less than that of novalgin.(69)

11. Cognitive behavior and Anti-anxiety Study: Saponins containing nbutanolic fraction extracted from dried leaves inhibited baclofen-induced hypothermia and passivity in amnesic mice. The studies showed that nbutanolic fraction possesses anxiolytic activity and nootropic activity.(70-71)

12. Immunomodulatory activity: Shirishavaleha prepared from Twak (Bark) and Sara (Heartwood) has shown significant immunomodulatory activity with Heartwood in comparison to Bark.(72)
Conclusion:

The plant has been attributed with a number of activities in the classics. The multi-dimensional activities have been revalidated in recent times on several experimental models and even in well designed clinical trials. The review reveals anti-anaphylactic, anti- asthmatic, antidiarrheal, anti-spermatogenic, anxiolytic, anti-inflammatory, anti-histaminic etc. activities of the plant in different forms. No study (of pre-clinical or clinical stages) reported any Adverse Reaction with the usage of the plant in crude form; which reveals the safety aspects of the plant.

\section{References:}

1. Wealth of India: A dictionary of Indian Raw Materials and Industrial Products. $1^{\text {st }}$ ed. Vol. I: A, New Delhi, CSIR; 2006. 126p.

2. Kirtikar K.R., Basu B.D., Revised by Blatter, Caius; Indian Medicinal Plants; 4:1311, (2000).

3. Chopra R.N., Badhwar R.L., Ghosh S., Poisonous Plants of India, volume 1,1984,352p.

4. Pokhriyal TC, et al. effect of VAM inoculation of growth and nitrogen age activity in Albizia lebbeck, Van. Vidnyan, 1992; 30(3-4):123-126.

5. Ayurvedic Pharmacopeia of India. Part-I. $1^{\text {st }}$ ed., Vol.3. New Delhi: Department of AYUSH, Ministry of Health and Family Welfare; 2001, $291 p$.

6. Sharma PV, Dravyaguna Vigyan. $1^{\text {st }}$ ed. Vol. II. Varanasi Chaukhambha Bharati academy; 2003. 774p.

7. Brahmashankar Mishra and Rupalalji Vaisya "Vatadi Varga Bhava Prakasha Nighantu" Varanasi: Chaukhambha Sanskrit Bhavan; 2007. 518p

8. Trpathi I, "Prabhadradi Varga Raja Nighantu" Varanasi: Chaukhambha Krishnadas Academy; 1998. 275p.

9. Sharma PV, Amradi Varga Sodhala Nighantu; Oriental Institute Baroda; 1978. 135p. 
10. Sharma PV, Sharma GP, "Aushadhi Varga Kaiyadeva Nighantu" Varanasi: Chaukhambha Orientalia; 2006, pp.180.

11. Jharkhand ojha and Umapati Mishra, "Amradi Varga Dhanvantari Nighantu" Varanasi: Chaukhambha Surbharti Prakashan; 2004. 227p.

12. Vd. Acharya J. T. Charaka Samhita, Fifth Edition, Varanasi, Chaukhambha Sanskrit Sansthan; Sutra Sthana 25/40, 2001,131p.

13. Kaviraj Ambikadtta Shashtri, Sushruta Samhita, Varanasi; Chaukhambha Sanskrit Sansthan, Sutra Sthana 39/14, 2005, 149p.

14. Vd. Acharya J. T. Charaka Samhita, Fifth Edition, Varanasi, Chaukhambha Sanskrit Sansthan; Chikitsa Sthana, 21/84, 2001, 564p.

15. Vd. Acharya J. T. Charaka Samhita, Fifth Edition, Varanasi, Chaukhambha Sanskrit Sansthan; Sutra Sthana 2/5, 2001, 24p.

16. Vd. Acharya J. T. Charaka Samhita, Fifth Edition, Varanasi, Chaukhambha Sanskrit Sansthan; Chikitsa Sthana, 23/193, 2001, 580p.

17. Vd. Acharya J. T. Charaka Samhita, Fifth Edition, Varanasi, Chaukhambha Sanskrit Sansthan; Chikitsa Sthana, 17/114, 2001, 536p.

18. Vd. Acharya J. T. Charaka Samhita, Fifth Edition, Varanasi, Chaukhambha Sanskrit Sansthan; Chikitsa Sthana 23/218, 2001, 580p.

19. Vd. Acharya J. T. Charaka Samhita, Fifth Edition, Varanasi, Chaukhambha Sanskrit Sansthan; Chikitsa Sthana 23/242, 2001, 581p.

20. Vd. Acharya J. T. Charaka Samhita, Fifth Edition, Varanasi, Chaukhambha Sanskrit Sansthan; Chikitsa Sthana 23/71, 2001, 575p.

21. Vd. Acharya J. T. Charaka Samhita, Fifth Edition, Varanasi, Chaukhambha Sanskrit Sansthan; Chikitsa Sthana 23/78, 2001, 575p.
22. Shastri Ambika Datta, Bhaishajya Ratnavali, Fifteenth Edition, Varanasi, Chaukhambha Sanskrit Sansthan; 72/72-74, 2002, 765p.

23. Kirtikar KR and Basu BD, Indian Medicinal Plants, New Delhi, Part II, 1980, 937p.

24. Chopra RN, Chopra IC, Handa KL, L.D. Kapur. Chopra's Indigenous Drugs of India. $2^{\text {nd }}$ ed reprinted Calcutta: Academic Publishers, 1982: 493p.

25. Kapoor LD, Handbook of Ayurvedic Medicinal Plants. Boca Raton: CRC Press, 1990: 23p.

26. Tripathi RM, Sen PC, Das PK. Studies on the mechanism of action of Albizzia lebbeck, an Indian indigenous drug used in the treatment of atopic allergy, J Ethnopharmacology, 1979; 1: 38596.

27. Thakur RS, Puri ES, Husain A. Major Medicinal Plants of India. Lucknow: Central Institute of Medicinal and Aromatic Plants, 1989, 39p.

28. Kirtikar K.R., Basu B.D., Revised by Blatter, Caius, Indian Medicinal Plants; 2000, 4,1311p.

29. El-Mousallamy. Amani MD. Leaf flavanoid of Albizia lebbeck., Phytochemistry 1998; 48(4):759-761.

30. Rashid RB, Chowdhury R, Jabbar A, Hasan CM and Rashid MA. Constituents of Albizia lebbeck and antibacterial activity of isolated flavone derivatives. Saudi Pharm. J., 2003; 11(1-2): 52-6.

31. Barua AK and Raman SP. The constitution of albigenic acid-A new triterpenoid sapogenin from Albizia lebbeck Benth. Tetrahedron, 1959; 7:19-23.

32. Asolkar LB, Kanitkar KK,Chakre OT. Glossary of Indian medicinal plants with active principle, part 1 , New Delhi, 1992, 38-39p.

33. Chopra RN, Chopra IC, Verma BS. Supplementary to glossary of Indian 
medicinal plants, New Delhi, 1969, 4$5 \mathrm{p}$.

34. Pal BC, Achari B, Yoshikawa K, Arihara S. Saponin from Albizia lebbeck. Phytochemistry, 1995; 38(5):1287-1291.

35. Tripathi VJ, Ray AB, Dasgupta B. Neutral constituents of Albizzia lebbeck, Current Science, 1974; 43: 46-48.

36. Rayuda GVN., Rajadurai S., Occurrence of D-catechin and leucocyanidin in bark of Albizia lebbeck. Leather Sci. (Madras), 1965; 12(1):21-22.

37. Shah CS., Bhattacharya AR., Pharmacognostical study of Albizia lebbeck Benth. Bark, Sci. Industr. Res., 1960; 19C, 199.

38. Kedare, B.S. and C.S. Tendolkar, "Destructive Distillation of Some Hardwood Species of Bombay State". J. Sci. Industr. Res., 1953; 12B, 217 221.

39. Shrivastava, K. Saxena, V.K. A new saponin from the roots of Albizia lebbeck. Fitoterapia, 1988; 59:479480.

40. Rayuda GVN., Rajadurai S., Occurrence of new flavanoid of lebbecacidin and melacacidin in heartwood of Albizia lebbeck. Leather Sci.(Madras), 1965; 12(10):362-363.

41. Wealth of India: A dictionary of Indian Raw Materials and Industrial Products. $1^{\text {st }}$ ed. Vol. I: A, New Delhi, CSIR; 2006.127-28p.

42. Wealth of India: A dictionary of Indian Raw Materials and Industrial Products. $1^{\text {st }}$ ed. Vol. I: A, New Delhi, CSIR; 2006.127p.

43. Wealth of India: A dictionary of Indian Raw Materials and Industrial Products. $1^{\text {st }}$ ed. Vol. I: A, New Delhi, CSIR; 2006. 126p.

44. Khajaria R.R., chemical composition of two fodder tree leaves Dhaman (Grewis elastica) and Shiris (Albizia lebbeck), Indian Veterinary Journal 1965; 42(10):789-792.

45. Khajaria R.R., Singh K., studies on chemical composition and digestibility of Shiris (Albizia lebbeck) fodder tree leaves, Indian Veterinary Journal 1968; 45(1):20-25.

46. Kumar S, Bansal P, Gupta V, Sannd $\mathrm{R}$, Rao MM. Clinical efficacy of Albizia lebbeck stem bark decoction on Bronchial asthma, International Journal of Pharmaceutical Science and Drug Research,2010; 2(1):48-50.

47. Jaiswal Mandeep, Prajapati PK., Ravishanker B., A comparative Pharmaceutico-Pharmaco-Clinical

Study of Shirisharishta prepared by Twak and Sara Kastha of Shirisha w.s.r. to it's Shwasahara Effect.(MD Thesis), 2007; Dept. Rasa Shastra and Bhaishjya Kalpana I.P.G.T. \& R.A, Jamnagar, Gujarat.

48. Agarawal Sweta, Baghel MS., Effect of Shireeshadighanavati in the management of Tamaka Shwasa w.s.r. to Bronchial Asthma. (MD Thesis), 2008; Dept. of Kayachikitsa \& Panchakarma I.P.G.T. \& R.A, Jamnagar, Gujarat.

49. Tripathi RM, Das PK, Studies on antiasthamatic and anti-anaphylectic activity of Albizia lebbeck, Indian J Pharma. 1977;9(3):189-194.

50. Tripathi RM, Sen PC, Das PK,. Studies on the mechanism of action of Albizzia lebbeck, an Indian indigenous drug used in the treatment of atopic allergy. J Ethnopharmacol. 1979; 1(4):385396.

51. Johri, R.K., Zutshi, U., Kameshwaran, L., and Atal, C. K. Effect of quercetin and Albizzia saponins on rat mast cell. Indian J. Physiol Pharmacol 1985; 29(1):43-46.

52. Shaw BP, Bera B, Treatment of tropical pulmonary eosinophilia with Shirisha flower (Albizia lebbeck Benth.) churna. Nagarjuna, 1986; 29 (6): 1-3 
53. Shyamlal Singh Yadav, Galib, Prajapati PK, Ravishanker B, Asok BK,. Evaluation of Anti-tussive activity of Shirishavaleha -An Ayurvedic Herbal Compound Formulation in Sulphur Dioxide induced Cough in mice, Indian Drugs, 2010; 47(9):38-41

54. Mukhopadhyay B., Nagarjana K., Sharma K. R., J. Res. Edu. Ind.Med. 1992;11(4):17-23,

55. Gupta RS, Kachhawa JB and Chaudhary R. Antifertility effects of methanolic pod extract of Albizia lebbeck Benth. in male rats. Asian J. Androl., 2004; 6(2): 155-159.

56. Gupta RS, Chaudhary R, Yadav RK, Verma SK and Dobhal MP. Effect of Saponins of Albizia lebbeck Benth. bark on the reproductive system of male albino rats, J. Ethnopharmacol., 2005; 96(1-2): 31-36.

57. Vohora SB, Khan MS. Antifertility studies on unani herbs. Part 3. Antiovulatory effects of two plant saponins, Indian J.Pharm 1974; 36:7779.

58. Settee B.S., Kamboj V.P., Garg H.S., Kanna N.M., Spermicidal potential of saponin isolated from Indian medicinal plants. Contraception, 1976, 14(5):571-578.

59. Settee B.S., Kamboj V.P., Garg H.S., Kanna N.M., screening of Indian plants for biological activity part VII, spermicidal activity of Indian plants. Ind. J. Exp. Biol. 15, 231-232.

60. Varshney IP, Vyas P, Srivastava HC, Singh PP., Study of Albizzia lebbek Benth wood saponin, Lebbekanin-E, Natl Acad Sci Lett (India), 1979; 2(4): 135-136.

61. Acharya S. Patra A.Prasasnta K. Evaluation of the Antimicrobial Activity of Some Medicinal Plants against Enteric Bacteria with Particular Reference to Multi-Drug Resistant Vibrio cholera, Tropical Journal of
Pharmaceutical Research, 2009; (3):231-237

62. N.B. Ganguly and E.M. Bhatt. Mode of action of active principle from stem bark of Albizia lebbeck. Indian J Exp Bio. 31:125-129(1993)

63. Bhatnagar S. S., Santapau, H., Desa, J. D. H., Maniar, A. C., Ghadially, N. C., Soloman, M. J., Yellore, S. and Rao, T. N. S., Biological activity of Indian medicinal plants. Part I. Antibacterial, antitubercular and antifungal action. Indian J Med Res, 1961; 49: 799-813.

64. Achinto Saha, Ahmad Muniruddin, The analgesic and anti-inflammatory activities of the extract of Albizia lebbeck in animal model, Pak. J. Pharm. Sci., 2009; 22(1):74-77.

65. Shyamlal Singh Yadav, Galib, B. Ravishankar, Prajapati P. K., Asok B. K., Varun B. Anti inflammatory activity of Shirishavaleha - An Ayurvedic compound formulation. International Journal of Ayurveda Research,2010;1(4):205-7

66. Pratibha N, Saxena VS, Amit A, D'Souza P, Bagchi $M$ and Bagchi D. Anti-inflammatory activities of Aller7, a novel polyherbal formulation for allergic rhinitis, Int. J. Tissue. React., 2004; 26(1-2): 43-51.

67. Achinto Saha, Ahmad Muniruddin, The analgesic and anti-inflammatory activities of the extract of Albizia lebbeck in animal model, Pak. J. Pharm. Sci., 2009; 22(1):74-77

68. Whittle BA. The use of changes in capillary permeability in mice to distinguish between narcotic and nonnarcotic analgesics; Br. J. Pharmacol. Chemo- therp., 1964,22: 246-253.

69. Gupta R.A., Singh B.N.,Singh R.N.,J. Screening of ayurvedic drugs for analgesic activity. Sci. Res. Plant Med. 1982; 3:115-117.

70. Chintawar SD, Somani RS, Kasture VS and Kasture SB., Nootropic activity of Albizia lebbeck in mice. J. 
Ethnopharmacol., 2002; 81(3): 29905.

71. Kasture VS, SB, Pal SC, Anticonvulsant activity of Albizzia lebbeck leaves,Indian journal of Experimental Biology. 1996; 34(1):7880.
72. Shyamlal Singh Yadav, Galib, B. Ravishankar, Prajapati P. K., Ashok B.K., Evaluation of Immunomodulatory activity of "Shirishavaleha" - An Ayurvedic compound formulation in albino rats. Journal of Ayurveda and Integrative Medicine, 2011: 2(4): 192-6. 